\title{
Pengembangan Bahan Ajar Geografi Berbasis Pendidikan Karakter Pada Materi Mitigasi dan Adaptasi Bencana
}

\author{
${ }_{1}^{1}$ Mei Vita Romadon Ningrum*, ${ }^{2}$ Yulian Widya Saputra \\ 1,2 Pendidikan Geografi FKIP Unversitas Mulawarman
}

Korespondensi: *mei_vita@yahoo.com

\begin{abstract}
Abstrak
Penelitian ini bertujuan untuk menghasilkan bahan ajar geografi yang mengintegrasikan dimensi kognitif, afektif, perilaku, dan mampu membentuk karakter siswa yang terkait dengan nilai peduli lingkungan serta untuk mengukur kelayakan dan keefektifan bahan ajar geografi untuk pembelajaran ditinjau dari hasil belajar. Teknik pengumpulan data yang digunakan dalam penelitian ini adalah dengan angket dan tes. Teknik analisis data menggunakan deskriptif kualitatif. Rancangan ini menggunakan penelitian dan pengembangan (research dan development) yang diadaptasi dari model Borg and Gall dan Dick and Carey dengan tahapan: Analisis kebutuhan, desain pengembangan, memproduksi/ mengembangkan bahan ajar, dan validasi. Hasil penelitian pengembangan menunjukkan bahwa kualitas bahan ajar sangat baik dan layak digunakan dalam pembelajaran. Pada aspek kelengkapan isi, terkategori sangat baik (skor rerata 4,32), aspek penyajian materi terkategori baik (skor rerata 4,16), aspek bahasa terkategori baik ( skor rerata 4,17), aspek kegrafikaan terkategori sangat baik ( skor rerata 4,22) dan aspek karakter terkategori sangat baik (skor rerata 4,34). Bahan ajar yang dikembangkan teruji efektif da lam meningkatkan hasil belajar siswa yaitu sebesar 27,71 point. Sehingga dapat disimpulkan bahwa bahan ajar yang dikembangkan berhasil dalam meningkatkan hasil belajar siswa.
\end{abstract}

Kata Kunci: Pengembangan Bahan Ajar, Geografi, Pendidikan Karakter

\section{Developing Geography Teaching Materials based on Character Education Focusing on Disaster Mitigation and Adaption Topic}

\begin{abstract}
This study aims to develop geography teaching materials that integrate cognitive, affective, behavioral dimensions, and are able to shape student character related to the value of environmental care and to measure the feasibility and effectiveness of geography teaching materials for learning in terms of learning outcomes. Data was collection techniques use questionnaires and tests. The data analysis technique used in this research is descriptive qualitative. This design uses research and development (research and development) which is adapted from the Borg and Gall and Dick and Carey models with the stages: Needs analysis, development design, producing / developing teaching materials, and validation. The results of development research show that the quality of teaching materials is very good and suitable for use in learning. In the aspect of completeness of the content, it is categorized very well (mean score 4.32), material presentation aspect is good category (mean score 4.16), language aspect is good category (mean score 4.17), graphic aspect is very good category (mean score 4,22 ) and the character aspects were very good (mean score 4.34). The teaching materials developed were tested to be effective in increasing student learning outcomes by 27.71 points. So it can be concluded that the teaching materials developed were successful in improving student learning outcomes.
\end{abstract}

Keywords: Development of Teaching Material, Geography, Character Education

Pengembangan Bahan Ajar Geografi ...

Mei Vita Romadon Ningrum, Yulian Widya Saputra 


\section{Pendahuluan}

Pendidikan merupakan upaya sadar dalam mengembangkan potensi peserta didik melalui interaksi dengan manusia dan lingkungan. Proses interaksi tersebut berlangsung dan dialami seumur hidup, baik berupa interaksi dengan lingkungan alam maupun lingkungan sosial. Dalam sistem pendidikan nasional jelas tertuang bahwa tujuan pendidikan selain membentuk siswa terampil dan cerdas, juga harus beriman, bertakwa, berakhlak mulia, mandiri, kreatif, supaya menjadi warga negara yang demokratis dan bertanggung jawab. Secara filosofis, misi pendidikan pada hakikatnya untuk memuliakan martabat manusia sebagai makhluk individual dan makhluk sosial yang berbudaya, sehingga dapat disimpulkan bawa pendidikan merupakan usaha yang untuk membangun budaya dan karakter bangsa Indonesia. Sesuai dengan Permendiknas RI (Peraturan Menteri Pendidikan Nasional Republik Indonesia) No.3 Tahun 2008, bahwa "kegiatan inti" merupakan proses pembelajaran untuk mencapai KD (Kompetensi Dasar). Proses pembelajaran ini untuk membentuk karakter yang diharapkan dalam pendidikan di Indonesia (Depdiknas RI, 2008).

Geografi sebagai salah satu mata pelajaran berperan dalam menanamkan nilai-nilai positif yang akan menjadi budaya dan karakter pada diri peserta didik. Salah satu nilai karakter yang dapat dibangun pada diri peserta didik melalui pembelajaran geografi yaitu peduli lingkungan. Sikap peduli lingkungan merupakan nilai karakter penting yang perlu dimiliki peserta didik, karena dalam kehidupan sehari-hari setiap orang akan selalu berinteraksi dan hidup dalam lingkungan. Pembelajaran geografi menekankan pada hubungan timbal balik yang "balance" antara manusia dan lingkungan tempat tinggal berada. Banyaknya permasalahan lingkungan yang terjadi seperti banjir, kebakaran hutan, polusi udara menjad indikasi betapa lemahnya kesadaran masyarakat terhadap pelestarian lingkungan sekitar. Kesadaran untuk melestarikan lingkungan sekitar diawali dengan pengetahuan yang baik dan benar tentang hakikat dan fungsi lingkungan terhadap kehidupan secara umum. Setelah itu diinternaslisasi dalam sikap dan diwujudkan dalam tindakan nyata sehari-hari. Hal tersebut sesuai dengan pendapat Lickona (2001), character education as a program that strives encompass the following: the cognitive, affective, and behavioral aspects of morality. Maksudnya bahwa pendidikan karakter meliputi aspek pemikiran, sikap, dan perilaku.

Pengembangan pendidikan karakter sangat strategis bagi keberlangsungan dan keunggulan bangsa di masa mendatang. Pengembangan harus dilakukan melalui perencanaan yang baik, pendekatan yang sesuai, serta metode belajar dan pembelajaran Pengembangan Bahan Ajar Geografi ... 
Jurnal geoedusains, Volume 1, Nomor 2, Desember 2020

yang efektif ( Zuchdi: 2010). Sesuai dengan sifat suatu nilai, pendidikan karakter bangsa adalah usaha bersama sekolah, keluarga dan lingkungan. Oleh karenanya, dalam lingkup sekolah harus dilakukan secara bersama oleh semua guru dan pemimpin sekolah, melalui semua mata pelajaran, dan menjadi bagian yang tak terpisahkan dari budaya sekolah (Sugandi, 244: 2015).

Bahan ajar merupakan bagian penting dalam proses pembelajaran. Bahan ajar dijadikan sebagai salah satu sumber informasi materi yang penting bagi guru maupun siswa. Keberadaan bahan ajar sangat penting karena bahan ajar merupakan komponen yang harus dikaji, dicermati, dipelajari dan dijadikan bahan materi yang akan dikuasai oleh siswa dan sekaligus dapat memberikan pedoman untuk mempelajarinya (Hermawan, dkk. 2008). Selain itu, bahan ajar harus dapat membuat peserta belajar secara mandiri, dapat belajar kapan saja dan dimana saja, sesuai dengan kecepatan masing-masing, mampu membuat peserta didik belajar urutan yang dipilihnya sendiri, membantu mengembangkan potensi peserta didik menjadi pelajar yang mandiri, dan sebagai pedoman bagi peserta didik mengarahkan semua aktivitas dalam proses pembelajaran dan menguasai semua kompetensi yang sudah ditentukan. (Depdiknas, 2010).

Berdasarkan observasi, bahan ajar yang dipakai oleh guru belum memperhatikan kondisi siswa dan lingkungannya, karena pada umumnya guru menggunakan bahan ajar komersial sebagai pegangan dalam pembelajaran. Hal tersebut menyebabkan guru tergantung pada bahan ajar komersial. Ketergantungan guru terhadap bahan ajar komersial sangat tinggi. Guru lebih memilih untuk membeli bahan ajar dari penerbit dibandingkan dengan membuat bahan ajar sendiri. Alasannya bervariasi, mulai dari kepraktisan, tidak adanya waktu dan kurangnya dana dalam membuat bahan ajar serta kemampuan guru dalam membuat bahan ajar tersebut. Padahal idealnya seorang guru harus mampu mengembangkan bahan ajar untuk menunjang pembelajaran, karena pengembangan bahan ajar merupakan salah satu upaya dalam meningkatkan mutu pendidikan. Selain itu, bahan ajar yang dikembangkan oleh guru akan lebih mudah dipahami siswa, karena seorang guru lebih karakter peserta didiknya dan lebih memahami kondisi lingkungan tempat tinggal sekitar siswa sehingga pembelajaran yang dilakukan akan lebih kontekstual dan menyenangkan.

Mitigasi dan adaptasi bencana alam merupakan salah satu dari materi pembelajaran geografi di SMA yang berisi tentang kondisi Indonesia yang rawan bencana, pada materi ini peserta didik memerlukan banyak informasi terkait dengan kondisi lingkungan yang menjadi penyebab dan dampak dari berbagai jenis bencana yang terjadi.

Pengembangan Bahan Ajar Geografi ...

Mei Vita Romadon Ningrum, Yulian Widya Saputra 
Jurnal geoedusains, Volume 1, Nomor 2, Desember 2020

Berdasarkan permasalahan di atas, maka peneliti tertarik untuk mengadakan penelitian dengan judul " pengembangan bahan ajar geografi berbasis pendidikan karakter pada materi mitigasi dan adaptasi bencana".

\section{Metodologi}

Penelitian ini menggunakan metode penelitian dan pengembangan (Research \& Development). Produk yang dikembangkan berupa bahan ajar pada materi mitigasi dan adaptasi bencana yang layak sebagai sumber belajar pada mata pelajaran geografi. Dalam penelitian ini digunakan model pengembangan prosedural yang diadaptasi dari model Borg \& Gall (1983) dan Dick \& Carey (2005) yang dilakukan melalui 4 tahapan utama, yaitu: 1) analisis kebutuhan (need analisis), 2) desain pengembangan, 3) memproduksi/ mengembangkan bahan ajar, dan 4) validasi/ evaluasi bahan ajar. Prosedur penelitian dalam penelitian ini dapat dijelaskan dengan gambar di bawah ini:

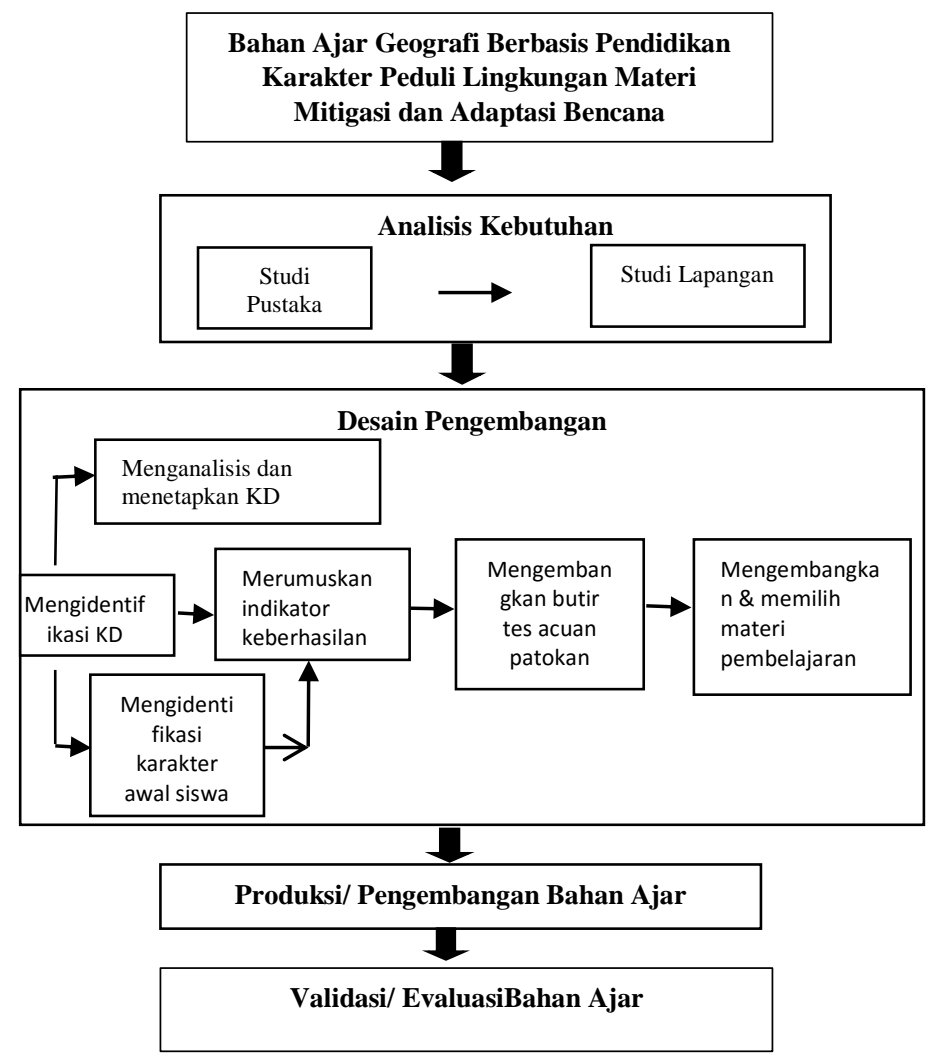

Populasi dalam penelitian ini adalah seluruh siswa kelas XI IPS tahun akademik 2017/ 2018 SMA Negeri 1, SMA Negeri 3, dan SMA Negeri 5 Samarinda yang berjumlah 311 siswa. Dengan jumlah sampel penelitian sebanyak 97 siswa. Teknik pengambilan sampel dilakukan dengan teknik cluster sampling atau teknik berdasarkan kelompok (kelas) sehingga setiap sekolah dipilih 1 kelas yang dianggap mewakili populasi dari Pengembangan Bahan Ajar Geografi ... 
Jurnal geoedusains, Volume 1, Nomor 2, Desember 2020

masing-masing sekolah. Data dalam penelitian ini, dikumpulkan dengan menggunakan instrumen: Tes hasil belajar, dan lembar penilaian bahan ajar oleh pakar dan siswa.

Teknik analisis deskriptif kualitatif digunakanuntuk mengetahui kelayakan bahan ajar yang dikembangkan. Data berupa komentar, saran revisi dari para ahli dan siswa serta hasil pengamatan peneliti selama proses uji coba analisis secara deskriptif kualitatif dan disimpulkan sebagai masukan untuk memperbaiki atau merevisi produk yang telah dikembangkan. Sedangkan data yang berupa skor ahli materi dan siswa yang diperoleh melalui kuesioner, dianalisis secara deskriptif kuantitatif dengan teknik persentase dan kategorisasi. Adapun kriteria penskoringan mengikuti ketentuan pada tabel di bawah ini:

Tabel . Kriteria Kelayakan Bahan Ajar

\begin{tabular}{ccc}
\hline Nilai & Interval & Kriteria \\
\hline A & $X>4,21$ & Sangat Baik \\
\hline B & $3,40<X \leq 4,21$ & Baik \\
\hline C & $2,60<X \leq 3,40$ & Cukup \\
\hline D & $1,79<X \leq 2,60$ & Kurang \\
\hline E & $X \leq 1,79$ & Sangat Kurang
\end{tabular}

Penelitian ini, menetapkan nilai kelayakan produk minimal "C", dengan kategori "Cukup" sebagai hasil penilaian baik dari ahli materi, ahli desain pembelajaran dan siswa. Jika hasil penilaian akhir (keseluruhan) pada aspek materi dengan nilai minimal " $C$ " (cukup) oleh para ahli, dan jika hasil penilaian akhir (keseluruhan) dengan nilai minimal "C" (cukup) oleh siswa, maka produk hasil pengembangan tersebut sudah dianggap layak digunakan sebagai sumber belajar. Untuk mengetahui keefektifan bahan ajar dalam meningkatkan hasil belajar siswa dilakukan analisis terhadap efektifitas bahan ajar pembelajaran geografi dalam meningkatkan hasil belajar dilakukan dengan pre test dan post test. Sehingga dapat diketahui perbedaan mean (rerata skor) antara skor pre test dan post test. Apabila perbedaan mean antara hasil pre test dan post test diperoleh signifikan, maka bahan ajar tersebut efektif digunakan untuk pembelajaran

\section{Pembahasan}

Pada penelitian ini pengembangan bahan ajar diawali dengan melakukan analisis kebutuhan berupa studi pustaka yakni penelusuran bahan ajar yang dipergunakan di tiga sekolah, didapatkan hasil bahwa bahan ajar yang dipergunakan seluruhnya adalah bahan ajar terbitan penerbit komersial yaitu buku ajar penerbit Erlangga Karya K. Wardiyatmoko. Selanjutnya studi lapangan yakni dengan melihat kegiatan pembelajaran yang Pengembangan Bahan Ajar Geografi ... 
Jurnal geoedusains, Volume 1, Nomor 2, Desember 2020

dilaksanakan. Selanjutnya dilakukan tahap desain pengembangan dan produksi bahan ajar yang secara ringkas dapat dilihat pada gambar 1 di atas. Selanjutnya, bahan ajar yang telah diproduksi, divalidasi melalui uji kelayakan untuk mengetahui kualitas bahan ajar yang dikembangkan. Validasi dilakukan oleh 2 ahli, yaitu ahli materi dan ahli desain pembelajaran. Validasi materi dilakukan oleh Dr. Iya' Setyasih, M.Pd, sedangkan Validasi Desain Pembelajaran dilakukan oleh Dr. Sudarman, M.Pd dengan hasil sebagai berikut:

Tabel 2. Hasil Validasi Ahli

\begin{tabular}{llcccc}
\hline No & $\begin{array}{l}\text { Aspek yang } \\
\text { divalidasi }\end{array}$ & $\begin{array}{c}\text { Ahli } \\
\text { Materi }\end{array}$ & Kriteria & $\begin{array}{c}\text { Ahli } \\
\text { Desain }\end{array}$ & Kriteria \\
\hline $\mathbf{1}$ & Isi & 4,14 & Baik & 4,23 & Sangat Baik \\
\hline $\mathbf{2}$ & Materi & 3,9 & Baik & 4,28 & Sangat Baik \\
\hline $\mathbf{3}$ & Bahasa & 4,0 & Baik & 4,09 & Baik \\
\hline $\mathbf{4}$ & Kegrafikaan & 4,07 & Baik & 4,09 & Baik \\
\hline $\mathbf{5}$ & Karakter & 4,0 & Baik & 4,48 & Baik
\end{tabular}

Berdasarkan hasil validasi oleh para ahli, 2 dari 5 aspek yang dikembangkan sudah dinilai sangat baik. Selanjutnya bahan ajar direvisi berdasarkan masukan dan saran yang diberikan. Bahan ajar yang telah direvisi kemudian dilakukan ujicoba kepada pengguna (siswa kelas XI IS) yang berjumlah 97 siswa yang tersebar di 3 sekolah dengan tahapan ujicoba satu-satu/ one to one evaluation (9 siswa), ujicoba skala kecil/ small group evaluation (36 siswa) dan ujicoba skala besar / field trial (97 siswa).

Pada ujicoba skala satu-satu ( one to one evaluation) bahan ajar divalidasi oleh 9 siswa yang tersebar dalam 3 sekolah yang berbeda, didapatkan hasil sebagai berikut:

Tabel 3. Hasil Validasi One to One Evaluation

\begin{tabular}{llrc}
\hline No & Aspek yang divalidasi & Rerata & Kriteria \\
\hline $\mathbf{1}$ & Isi & 4,23 & Sangat Baik \\
\hline $\mathbf{2}$ & Materi & 4,28 & Sangat Baik \\
\hline $\mathbf{3}$ & Bahasa & 4,09 & Baik \\
\hline $\mathbf{4}$ & Kegrafikaan & 4,09 & Baik \\
\hline $\mathbf{5}$ & Karakter & 4,48 & Baik \\
\hline & Total & $\mathbf{4 , 2 2}$ & Baik
\end{tabular}

Komentar/ Saran yang diberikan oleh siswa yaitu:

1. Menambah latihan soal di setiap bab

Pengembangan Bahan Ajar Geografi ...

Mei Vita Romadon Ningrum, Yulian Widya Saputra 
Jurnal geoedusains, Volume 1, Nomor 2, Desember 2020

2. Kualitas gambar kurang bagus,

Pada ujicoba skala kecil (small group evaluation) bahan ajar divalidasi oleh 36 siswa, didapatkan hasil sebagai berikut:

Tabel 4. Hasil Validasi Small Group

\begin{tabular}{llrr}
\hline No & Aspek yang divalidasi & Rerata & Kriteria \\
\hline $\mathbf{1}$ & Isi & 4,21 & SangatBaik \\
\hline $\mathbf{2}$ & Materi & 3,70 & Baik \\
\hline $\mathbf{3}$ & Bahasa & 3,90 & Baik \\
\hline $\mathbf{4}$ & Kegrafikaan & 4,00 & Baik \\
\hline $\mathbf{5}$ & Karakter & 4,00 & Baik \\
\hline & Total & $\mathbf{3 , 9 6}$ & Baik \\
& & &
\end{tabular}

Komentar/ Saran yang diberikan oleh siswa:

1. Buku ini menurut saya layak digunakan, karena memiliki kalimat, contoh, serta penjelasan yang mudah dipahami ( Nurhilal)

2. Menurut saya, dari segi penyajian, bahasa dan karakter dalam buku ini sudah cukup baik, sehngga pembaca memiliki ketertarikan untuk menjaga kelestarian alam dan mampu membangkitkan rasa peduli kita terhadap alam (Siti Yusliwat).

Setelah mendapat saran dan masukan pada ujicoba skala kecil, tahap selanjutnya merevisi dan mengujicobaakan bahan ajar pada lingkup yang lebih besar. Ujicoba terakhir dilakukan oleh siswa satu kelas di 3 sekolah dengan total responden sebanyak 97 siswa dengan hasil sebagai berikut:

Tabel 5. Hasil Validasi Field Trial Evaluation

\begin{tabular}{llrr}
\hline No & Aspek yangdivalidasi & Rerata & Kriteria \\
\hline $\mathbf{1}$ & Isi & 4,7 & Sangat Baik \\
\hline $\mathbf{2}$ & Materi & 4,68 & Sangat Baik \\
\hline $\mathbf{3}$ & Bahasa & 4,62 & Sangat Baik \\
\hline $\mathbf{4}$ & Kegrafikaan & 4,67 & Sangat Baik \\
\hline $\mathbf{5}$ & Karakter & 4,86 & Sangat Baik \\
\hline & Total & $\mathbf{4 , 7 0}$ & SangatBaik
\end{tabular}

Hasil ujicoba yang yang dilakukan oleh ahli dan siswa menunjukkan bahwa bahan ajar geografi layak dipergunakan dalam pembelajaran. Pada aspek kelayakan isi, materi yang disajikan telah mencakup semua materi yang terkandung dalam kompetensi dasar Pengembangan Bahan Ajar Geografi ... 
Jurnal geoedusains, Volume 1, Nomor 2, Desember 2020

(KD) yaitu pada KD 3.7: menganalisis jenis dan penanggulangan bencana alam melalui edukasi, kearifan lokal, dan pemanfaatan teknologi modern. Selain itu materi disampaikan runtut mulai dari pengenalan konsep, definisi, prosedur, tampilan output, contoh, kasus, latihan, sampai dengan interaksi antar konsep sesuai dengan tingkat pendidikan peserta didik dan sesuai dengan yang diamanatkan oleh Kompetensi Dasar (KD). Serta dapat mencerminkan jabaran yang mendukung pencapaian semua Kompetensi Dasar (KD).

Pada aspek penyajian materi sistematika penyajian dalam setiap bab disajikan Konsistensi mulai dari pendahuluan, isi, dan diakhiri dengan latihan soal pada setiap akhir bab. Agar memudahkan pembaca dalam mendapatkan gambaran materi yang akan disampaikan pada setiap awal bab disajikan peta konsep dan kata kunci materi. Soal latihan diberikan di akhir bab sebagai upaya untuk mendorong rasa ingin tahu siswa sekaligus sebagai evaluasi dalam memahami materi yang disajikan. Contoh, gambar dan kasus yang disajikan juga aktual yang terjadi di Indonesia agar materi lebih mudah dipahami karena bersifat kontekstual.

Pada aspek kebahasaan, bahan ajar dinilai memiliki ketepatan struktur kalimat yang baik, artinya kalimat yang dipakai mewakili isi pesan atau informasi yang ingin disampaikan dan tetap mengikuti tata kalimat bahasa Indonesia serta kalimat yang dipergunakan sederhana langsung ke sasaran yang ingin disampaikan. Bahasa yang digunakan dalam bahan ajar ini sudah disesuaikan dengan tingkat perkembangan kognitif peserta didik.

Aspek kegrafikaan dalam bahan ajar ini telah sesuai dengan standar yang ditetapkan oleh badan standar nasional pendidikan (BSNP) yaitu berukuran B5 (716 x $250 \mathrm{~mm}$ ), penataan unsur tata letak pada cover muka, belakang dan punggung memiliki kesatuan, llustrasi dapat menggambarkan isi/ materi ajar tentang mitigasi dan adaptasi bencana, penempatan hiasan/ilustrasi sebagai latar belakang tidak mengganggu judul, teks, angka halaman sehingga keseluruhan ilustrasi serasi.

Aspek nilai karakter yang ingin dikembangkan dalam pengembangan bahan ajar ini terutama adalah nilai karakter peduli lingkungan, berdasarkan hasil validasi yang dilakukan diketahui bahwa isi materi secara keseluruhan mampu membangkitkan rasa kepedulian siswa terhadap lingkungan sekitar, mampu menginspirasi siswa dalam menjaga kelestarian alam, serta penyajian materi secara keseluruhan mampu memberikan gambaran kepada siswa tentang sikap perlunya menjaga keseimbangan lingkungan.

Pengembangan Bahan Ajar Geografi ...

Mei Vita Romadon Ningrum, Yulian Widya Saputra 
Jurnal geoedusains, Volume 1, Nomor 2, Desember 2020

Tahapan selanjutnya untuk mengetahui keefektifan bahan ajar yang dikembangkan, data dalam penelitian ini diperoleh melalui kegiatan pre test dan post test. Berdasarkan hasil pre test diketahui nilai rerata siswa adalah 51,61 dan post test nilai rata-rata siswa adalah 79,32, hal ini berarti terdapat peningkatan nilai sebesar 27,71 . Jika dilihat dari nilai per-siswa pada kegiatan pre test nilai terendah yaitu 25 (satu siswa) sedangkan nilai tertinggi yaitu 70 (empat siswa). Dengan hasil pre test ini tidak ada siswa yang mencapai KKM (kriteria ketuntasan minimum). Sedangkan pada kegiatan post test nilai terendah yaitu 70 (diperoleh dua siswa) sedangkan nilai tertinggi yaitu 95 (diperoleh tiga siswa). Berdasarkan nilai siswa, terdapat 84 atau $86,5 \%$ dari 97siswa telah mencapai nilai KKM, yang artinya bahan ajar yang dikembangkan dinilai efektif digunakan dalam pembelajaran.

\section{Kesimpulan}

Berdasarkan hasil penelitian dan pembahasan didapatkan kesimpulan bahwa pengembangan bahan ajar geografi berbasis pendidikan karakter dinilai layak dan efektif dalam meningkatkan hasil belajar, hal ini dibuktikan dengan rerata skor yang diperoleh yaitu 4,24 (Sangat Baik), serta peningkatan rerata hasil belajar sebesar 27,71 artinya sebanyak 84 atau $86,5 \%$ dari 97 siswa telah mencapai ketuntasan belajar

\section{Daftar Pustaka}

Asep H. Hermawan, dkk. 2008. Pengembangan Kurikiulum dan Pembelajaran. Jakarta: Universitas Terbuka.

Asymanidar, Dede Rohmat, Mamat Ruhimat (2013) Pengembangan Perangkat Pembelajaran Geografi Berbasis Pendidikan Karakter : Jurnal Pendidikan Geografi, Vol 13 No 1 Hal 1-12.

Borg, Walter.R. \& Gall, M.D. (1983). Educational Research: An Introduction.(4 ${ }^{\text {rd }}$ ed.). New York: Longman.inc. (2007). Educational research: an introduction. ( $8^{\text {rd }}$ ed.). New York: Pearson.inc

Darmiyati Zuchdi. (2010). Humanisasi pendidikan, menemukan kembali pendidikan yang manusiawi (edisi ketiga).Jakarta: Bumi Aksara.

Depdiknas. 2008. Panduan Pengembangan Bahan Ajar. Jakarta: Dirjen Pendidikan Dasar dan Menengah.

2010. Panduan Penyusunan Bahan Ajar Berbasis TIK. Jakarta: Direktorat Pembinaan Sekolah Menengah Atas.

Dick, W., Carey, L., dan Carey,J.O. 2005. The Systemic Design of Instruction. Fifth Edition. New York: Longman

Kementerian Pendidikan Nasional. (2010). Desain Induk Pendidikan Karakter. Jakarta, Kementerian Pendidikan Nasional.

Lickona, Thomas, E. Schaps \& C. Lewis. (2010). Eleven principles of effective character education.(Rev. ed.). Washington, D.C: Character Education Partnership.

Pengembangan Bahan Ajar Geografi ...

Mei Vita Romadon Ningrum, Yulian Widya Saputra 
Jurnal geoedusains, Volume 1, Nomor 2, Desember 2020

Lickona, Thomas. (1991). Educating for character. How our schools can teach respect and responsibility. New York: Bantam Books.

Majid abdul, 2007, perencanaan pembelajaran, bandung. Pt. Remaja rosdakarya

Sugandi, Dede. 2015. "Pembelajaran Geografi sebagai Salah Satu Dasar Pembentukan Karakter Bangsa" in SOSIOHUMANIKA: Jurnal Pendidikan Sains Sosial dan Kemanusiaan, Vol.8(2) November, pp.241-252.

Widodo, Chomsin S, dan Jasmadi 2008. Panduan menyusun bahan ajar berbasis kompetensi, jakarta. Gramedia. 